\title{
Metastatic Tumour of Spermatic Cords, Epididymis and Seminiferous Duct from Gastric Carcinoma
}

\author{
$\mathrm{F} \mathrm{Xu}^{1}$, Y Wang ${ }^{2}$
}

\begin{abstract}
Metastatic tumour of spermatic cords, epididymis and seminiferous duct from gastric carcinoma has been recently reported but rarely seen. A case of metastatic tumour from gastric carcinoma in a 50year old man is herein reported. The initial diagnosis was thickening of both spermatic cords. Needle biopsy of the spermatic cord, testicle and epididymis was performed. Pathological findings showed a gastric signet ring cell carcinoma. Thus, double radical orchiectomy was performed and metastatic signet ring cell carcinoma of the spermatic cord and testis was diagnosed through histological examination and immunohistochemistry. Physicians should be aware that gastric carcinoma is one of the possibilities for metastasis to the seminal duct.
\end{abstract}

Keywords: Double spermatic cord metastases, signet ring cell carcinoma, testicular carcinoma

\section{Tumor Metastásico de los Cordones Espermáticos, el Epidídimo y el Conducto Seminífero a Partir de un Carcinoma Gástrico}

\author{
$\mathrm{F} \mathrm{Xu}^{1}, \mathrm{Y} \mathrm{Wang}^{2}$
}

\begin{abstract}
RESUMEN
El tumor metastásico de los cordones espermáticos, el epidídimo y el conducto seminífero a partir de un carcinoma gástrico ha sido reportado recientemente, pero pocas veces visto. En este trabajo se reporta el caso de un tumor metastásico a partir de un carcinoma gástrico en un hombre de 50 año de edad. El diagnóstico inicial fue el engrosamiento de los dos cordones espermáticos. Se realizó una biopsia con aguja del cordón espermático, testículos y epidídimo. Los resultados patológicos mostraron un carcinoma de células en anillo de sello. Por consiguiente, se realizó una orquiectomía radical doble, y el carcinoma metastásico en anillo de sello del cordón espermático y el testículo, fue diagnosticado mediante examen histológico e inmunohistoquímico. Los médicos deben tener presente que el carcinoma gástrico es una de las posibilidades de metástasis en los conductos seminales.
\end{abstract}

Palabras claves: Doble metástasis en los cordones espermáticos, carcinoma de células en anillo de sello, carcinoma testicular

West Indian Med J 2013; 62 (9): 859

\section{INTRODUCTION}

Gastric cancer is one of the most common malignancies in the world $(1,2)$. Gastric cancer spreads by direct extension through the gastric wall and, therefore, surrounding tissues or organs such as the pancreas, colon or liver could be involved. It also spreads via the lymphatics or by seeding peritoneal

From: ${ }^{1}$ Department of Urology, The First Affiliated Hospital of Zhengzhou University, Zhengzhou, HeNan 450052, China and ${ }^{2}$ Department of Urology, Zunyi Hospital of Guizhou Providence, Zunyi, Guizhou 563000, China.

Correspondence: F Xu, Department of Urology, The First Affiliated Hospital of Zhengzhou University, Zhengzhou, HeNan 450052, China. E-mail: xufeng6602@163.com surfaces. Gastric cancer can also spread to the ovary and is called Krukenberg tumour. In the haematogenous spread of gastric cancer, the liver is the most common site. Compared with its counterpart, Krukenberg tumour $(3,4)$, which is most possibly spread via the lymphatics, the incidence of gastric cancer with metastasis to the spermatic cords, epididymis and seminiferous duct is quite rare. We present here an unusual case of gastric signet ring cell carcinoma that metastasized to both spermatic cords, epididymis and seminiferous duct.

\section{CASE REPORT}

A 50-year old male suffered dysuria, odynuria and frequent micturition five months ago. Physical examination showed 
thickening and hardening of both spermatic cords, testicle and epididymis. This was confirmed by ultrasonic examination. He denied other constitutional symptoms such as fever, epigastralgia, poor appetite and weight loss, but the patient felt intense pain in the spermatic cords, testicle and epididymis. The patient's history revealed that he had undergone partial gastrectomy for gastric carcinoma four years ago and radical gastrectomy for cancer relapse three years ago. Needle biopsy of the spermatic cords and testis was then performed. Pathological findings showed a gastric signet ring cell carcinoma. Thus, double radical orchiectomy was performed and metastatic signet ring cell carcinoma of the spermatic cord, epididymis and seminiferous duct was diagnosed by histological examination (Figure A-C). The spermatic cords were hardened and thickened with no obvious boundary with surrounding tissues. Figure D shows the specimens after surgery. The patient felt well postoperatively and the pain was gone.

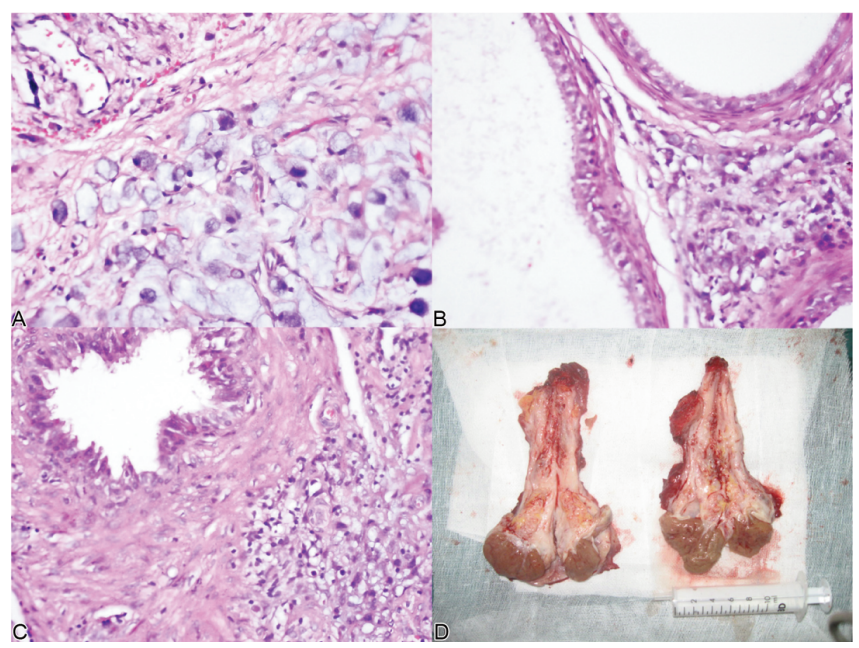

Figure: After double radical orchiectomy. Haematoxylin-eosin staining of gastric signet ring cell carcinoma of (A) spermatic cord, (B) epididymis and (C) seminiferous duct [all original magnification $\mathrm{x}$ 400]. (D) The specimens after surgery.

\section{DISCUSSION}

Krukenberg tumour is a well-known ovarian metastasis, usually from gastric signet ring cell carcinoma in female patients. Although gastric carcinoma is more frequent in men, to our knowledge only few cases of testicular metastases have been described. Furthermore, there is no report of metastasis to spermatic cords, epididymis and seminiferous duct from gastric carcinoma so far. This extremely rare form of metastatic dissemination resembles the Krukenberg tumour of the ovaries. Histological examination plays an important role in the differential diagnosis of spermatic cord enlargement. In addition to the lymphatic and vascular routes, several routes of metastasis to the epididymis and seminiferous duct have been postulated. These include retrograde extension through the vas deferens, through its lumen, the lymphatic channels in its wall, or as transperitoneal seeding along a patient's tunica vaginalis (5). In this case, metastatic dissemination through the vas deferens may be the main route for gastric cancer metastasis to the epididymis and seminiferous duct (Figure). Ultrasonography is the imaging modality of choice and may help cinch the diagnosis, especially in the presence of nodules and a recent diagnosis of another primary cancer. For this case, the patent's history, especially the history of metastasis is important in diagnosis. Finally, a definite diagnosis depends on the needle biopsy and histology.

\section{REFERENCES}

1. Ferlay J, Bray F, Parkin DM, Pisani P. Globocan 2000: cancer incidence and mortality worldwide. IARC Cancer Bases No. 5. Lyon: IARC Press; 2001.

2. Lau M, Le A, El-Serag HB. Noncardia gastric adenocarcinoma remains an important and deadly cancer in the United States: secular trends in incidence and survival. Am J Gastroenterol 2006; 101: 2485-92.

3. Turan T, Aykan B, Koc S, Boran N, Tulunay G, Karacay O et al. Analysis of metastatic ovarian tumors from extragenital primary sites. Tumori 2006; 92: 491-5.

4. Kakushima N, Kamoshida T, Hirai S, Hotta S, Hirayama T, Yamada J et al. Early gastric cancer with Krukenberg tumor and review of cases of intramucosal gastric cancers with Krukenberg tumor. J Gastroenterol 2003; 38: 1176-80.

5. Hasana RQ, Ramaswamy M, Foster C, Fordham MV. Testicular metastasis from gastric carcinoma. Urology 2006; 68: 4. 